\title{
Akuntansi Pemerintahan Di Simpang Jalan
}

\author{
Oleh : Revrisond Baswir
}

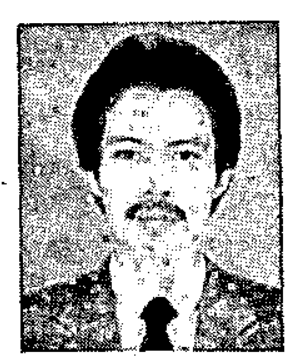

Revrisond Baswir, adalah Staf Pengajar pada Fakultas Ekonomi UGM, serta staf Pengajar dan staf Ahli pada Fakultas Ekonomi UGM tahun 1983. Semasa mahasiswa, disamping aktif menulis di berbagai media massa juga aktif, dalam berbagai kegiatan kemahasiswaan, al : Pemimpin Redaksi Majalah Mahasiswa FE-UGM EQUILIBRIUM, dan Anggota BKK-UGM, 1980-1982. Pada tahun 1983 terpilih sebagai Mahasiswa teladan IIUGM. Kini, disamping mengajar, juga menjadipemimpin Redaksi JURNAL EKONOMIDANBISNISINDONESIA, FE-UGM, dan aktif sebagai Peneliti pada Pusat Penelitian Pembangunan Pedesaan dan Kawasan (P3PK)-UGM.

\section{Pendahuluan}

Pengajaran akuntansi di Indonesia tampaknya telah dengan sengaja dipilah menjadi dua bagian. Bagian pertama adalah pengajaran akutansi perusahaan. Sedangkan bagian kedua adalah pengajaran akutansi pemerintahan. Bila pengajaran akutansi perusahaan diselenggarakan oleh jurusanjurusan akutansi pada Perguruan Tinggi Negeri dan Swasta (PTN/PTS), yang bernaung di bawah pengelolaan Departemen Pendidikan dan Kebudayaan, maka pengajaran akutansi pemerintahan diselenggarakan oleh Sekolah Tinggi Akutansi Negara (STAN), yang bemaung di bawah pengelolaan Departemen Keuạngan.

Pemilahan pengajaran akuntansi menjadi dua bagian ini temyata tidakhanya menyebabkan timbulnya persoalanpersoalan akademik, tapi kemudian juga menyebabkan timbulnya persoalanpersoalan yang semata-mata administratif. Salah satu contoh persoalan administratif yang bersumber dari pemilahan pengajaran akutansi itu adalah persoalan penggunaan gelar kesarjanaan oleh para lulusan STAN. Menurut ketentuan yang berlaku, pemberian gelarkesarjanaan ternyata hanya boleh dilakukan oleh perguruan-perguruan tinggi yang bemaungdi bawah Departemen Pendidikan dan Kebudayaan. Akibatnya, karena STAN tidak bemaung di bawah Departemen Pendidikan dan Kebudayaan, melainkan di bawah Departemen Keuangan, maka ia tidak memiliki otoritas untuk memberi gelar kesarjanaan kepada para lulusannya.

Hilangnya hak para lulusan STAN untuk menyandang gelar kesarjaan itu, secara tidak langsung menimbulkan kesan bahwa hanya mereka yang mempelajari 
akuntansi perusahaan lah yang berhak menyandang gelarkesarjanaan. Sedangkan mereka yang mempelajari akutansi pemerintahan, tidak layakmenyebutdirinya sebagai sarjana.

Tujuan tulisan ini bukanlah untuk mengkaji soal hak kesarjanaan para lulusan STAN tersebut. Yạng ingin dikaji di sini adalah mengenai pengajaran akutanși pemerintahan padajurusan-jurusan akutansi PTN/PTS di Indonesia, terutama dilihat dari sudut tantangan perkembangan masa depan.

\section{Di Simpang Jalan}

Persoalan pengajaran akuntansi pemerintahan pada jurusan akutansi PTN/ PTS di Indonesia sebenarnya bukan merupakan persoalan baru. Tanpa memperhitungkan perkembangan masa depan pun sesungguhnya pengajaran akutansi pemerintahan hampir selaiu berada di simpang jalan. Situasi sulit pengajaran akutansi pemerintahan ini terutama bersumber dari hal-hal sebagai berikut : Pertama, berlanjutnya metode tata buku tunggal warisan Belanda sebagai metode pembukuanpemerintah. Kedua, beralihnya orientasi pengajaran akutansi,di Indonesia ke Amerika Serikat (AS), dan ketiga, terdapatnya perbedaan yang sangat menyolok antara sistem pemerintahan Indonesia dengan sistem pemerintahan AS.

\section{Tata Buku Tunggal}

Sebagaimana diketahui, metode pengeloläan keuangan negara Indonesia hingga saat ini masih merupakan warisan pemerintahan Belanda. Ini tidak hanya tampak pada wujud metode yang dipakai, akan tetapi juga dapat dilacak secara langsung pada aturan-aturan yang mendasari penggunaan metode tersebut. Dengan perkecualian beberapa perbaikan parsial yang dilakukan belakangan, secara keseluruhan kebijakan pengelolaan keuangan negara di Indonesia masih didasarkan atas aturan-aturan yang terangkum di dalam Undang-Undang Perbendaharaan Indonesia (Indische Comptabiliteit Wet).

Bukti paling nyata bahwa pengelolaan keuangan negara Indonesia masih di dasarkan atas metode warisan Belanda adalah pada penggunaan metode tata buku tunggal sebagai metode pembukuan pemerintah. Metode ini jelas banyak kelemahannya. Sebagai misal, metode pencatatannya yang bersifat pembukuan tunggal, menyebabkan timbulnya kesulitan dalam melakukan pemerikasaan. Pengecekan langsung sebagaimana halnya pada pembukuan berpasangan, tidakdapatdilakukan(Purba, 1988).

Yang lebih memprihatinkan adalah dampak kelemahan metode ini terhadap penyusunan Perhitungan Anggaran Negara (PAN). Sifatnya yang tidak lebih sebagai sekedar catatan uang keluar-masuk bendaharawan, menyebabkan penyusunan PANbaru dapat diselesaikan sekitar 3 tahun setelah berakhimya tahun anggaran. Ini tentu sangat terlambat. Sehingga PAN dalam hal ini tidak lagi relevan untuk digunakan sebagai alat evaluasi terhadap kinerja pemerintah.

Dilihat dari sudut pengajaran akuntansi. pemerintahan, situasi sebagaimana di atas tentu menimbulkan masalah. Di satupihak, penggunaan metode buku tunggal sebagai metode pembukuan pemerintah adalah suatu fakta. Akan tetapi, dengan berbagai kelemahannya, tampaknya dirasa kurang tepat bila ia dimasukkan sebagai bagian dari pengajaran akuntansi pemerintahan. Bahkan, karena ada yäng beranggapan bahwa tata bukku bukanlah 
akuntansi (Sajihartana, 1992), tampaknya ia memang tidak sepatutnya disertakan dalam pengajaran akutansi pemerintahan.

\section{Oriensi Pengajaran Akutansi}

Walaupun pengajaran akuntansi yang berorientasi ke AS baru dilakukan secara besar-besaran sejak dua dekade belakangan ini, pergeseran orientasi pengajaran akutansi Indonesia ke AS sebenamya sudah berlangsung sejak tahun 1958 (Hadibroto, 1977). Dampak pergeseran orientasi ini terutama sangat terasakan pada terjadinya pergeseran dari metode pembukuan tunggal ke metode pembukuan berpasangan.

Dilihat dari sudut pengajaran akutansi pemerintahan, pergeseran orientasi ini kemudianjuga menyebabkan munculnya keinginan untuk mengadopsi metode pembukuan pemerintah AS yang dikenal sebagai akutansi dana. Bukti kuatnya keinginanuntukmengadopsi akutansi dana ini dapat dilihat padacakupanmateri silabus minimal Akutansi Pemerintahan, sebagaimana digariskan oleh Konsorsium Ilmu Ekonomi berikut ini :

(1) Pendahuluan; tujuan akutansi pemerintahan, ikhtisar ringkas jalannya pengurusan keuangan negara RI, ikhtisar ringkas dana-dana (funds) yang dimiliki olehnegara AS sérta tujuan/kegunaandanadana tersebut.

(2) Siklus Anggaran Negara; penyusunan dan pengelolaan serta pelaksanaan anggaran, pengawasan pelaksanaan anggaran, proses penerbitan SKO, SPMU dan SPJ.

(3) Pengurusan Keuangan Negara; pengurusan comptabel, administrasi barang, cara pengadaan dan penjualan barangbarang negara serta proses akutansinya.

(4) Fund Accounting; proses akuntansinya, penutupan buku, proses penyusunan laporan intem dan laporan akhir tahun.

Bila diperhatikan secara cermat, penyusunan silabus minimal Akuntansi Pemerintahan di atas tampaknya sangat sadar bahwa di satu pihak, Akuntansi Dana adalah akuntansi pemerintahan AS; sedang di pihak lain, Akuntansi Dana tidak atau belum diterapkan di Indonesia. Bahwa Akuntansi Dana tetap dimasukkan sebagai bagian dari silabus minimal Akuntansi Pemerintahan ini tentu didasarkan atas keyakinan bahwa suatu ketika, pembukuan pemerintahan Indonesia akan diselenggarakan dengan menerapkan metode akutansi dana tersebut.

Yang tampaknya tidak dipikirkan secara cennat dalam penyusunan silabus ini adalah mengenai terjadinya pencampur adukkan materi-materi yang berbeda ke dalam satu paket pengajaran. Di satu pihak, pembicaraan mengenai pengelolaan keuangan negara Indonesia lebih banyak ditekankan pada aspek pengurusan administrasinya. Sedangkan di pihak lain, pembahasan mengenai akutansi dana seluruhnya berbicara mengenai metode pembukuan. Dengan demikian, anggapan seolah-olah pengajaran Akuntansi Pemerintahan adalah semacam suatu studi perbandingan, juga sulit untuk diterima.

\section{Sistem Pemerintahan}

Hal lain yang patut dipertanyakan sehubungan dengan dimasukkannya akuntansi dana sebagai bagian dari pengajaran akutansi pemerintahan adalah mengenai peluang penerapannya di Indonesia. Pertanyaan ini layak diajukan mengingat terdapatnya perbedaan yang sangat menyolok antara sistem pemerintahan Indonesia dengan sistem pemerintahan AS.

Di satu pihak, sistem pemerintahan Indonesia bersifat sentralistis. Sedangkan 
di pihak lain, sistem pemerintahan AS ini tentu sangat besar pengaruhnya terhadap pengelolaan keuangan negara masingmasing negara. Karenasistem pemerintahan Indonesia bersifat sentralistik maka pengelolaan keuangan negaranya pun bersifat sentralistik. Di AS, karena tiap-tiap tingkat pemerintah bersifat otonom maka pengelolaan keuangannya pun bersifat otonom pula. 1

Implikasi langsung dari perbedaan sistem pemerintahan ini terlihat secara jelas pada tingkat pemerintahan yang dijadikan objek bahasan. Dalam membicarakan pengurusan keuangan negara di Indonesia, tingkat pemerintahan yang menjadi objek bahasan adalah pemerintah pusat. Sebaliknya, dalam membicarakan praktik akuntansidana di AS, tingkatpemerintahan yang menjadi objek bahasan adalah pemerintahan daerah tingkat kotamadya, kabupaten dan bahkan setingkatkecamatan. Pendek kata, tanpa adanya perubahanperubahan mendasar dalam sistem pemerintáhan dan kebijakan pengelolaan keuangan negara Indonesia, kecil peluang bagi penerapan akutansi dana di Indonesia.

Bertitik tolak dari pembahasan tiga hal di atas, kiranya dapat dilihat bahwa pengajaran akuntansi pemerintahan selama ini memang selalu berada di simpang jalan. Yang cukup mengejutkan adalah bahwa dalam kenyataan di lapangan ternyata tidak sedikit pengajar yang hanya mengajarkan akutansi dana sebagai materi ajaran akutansi pemerintahannya. Ini tentú sangat menyimpang dari tujuan pengajaran akuntansi yang sebenamya. Sebagai suatu paket teknologi, tiap-tiap materi ajaran akutansi harus relevan dengan kebutuhan praktik.

\section{Tantangan Masa-Depan}

Bila situasi kekinian pengajaran akutanși pemerintahan sudah berada di simpangjalan, makapersoalan menjadi kian kompleks bila diperhatikan pula perkembangan yang tidak akan terjadi di masa depān. Setidak-tidaknya ada dua issue penting yang perlu dikaji sehubungan dengan tantangan masa depan pengajaran akutansi pemerintahan di Indonesia: Pertama, penyusunan Akutansi Pemerintahan Baru; dan kedua; peningkatan otonomi daerah dalam manajemen pemerintahan Indonesia.

\section{Akutansi Pemerintahan Baru .}

Sebagaimana diketahui, penyusunan sistem akutansi pemerintahan baru untuk pemerintah pusat dimulai pada tahun 1982. Yang bertindak selaku penyusun adalah lembaga konsultan SGV dari Pilipina. Setelah cetak birunya disusun pada tahun 1987, sejak tahun 1988 sistem akuntansi pemerintahan baru ini mulai diujicobakan pada beberapa departemen tertentu di beberapapropinsi. Diantaranya adalah pada departemen keuangan, departemen sosial, departemen pekerjaan umum dan departemen perdagangan.

Ada beberapa halmenarik yang perlu untuk dicatat sehubungan dengan sistem akutansi pemerintahan baru ini.

Pertama, dilihat dari sudut anggapan yang dipakai, penyusunan sistem akutansi pemerintahan baru ini jelas sekali didasarkan pada anggapan bahwa tatanan pemerintahan Indonesia di masa depan akan tetap bersifat sentralistis. Itu misalnya tampak pada unit-unit kelembagaan yang perlu dibentuk untuk pengoperasiannya seperti: Kantor Pusat' Akutansi, Unit Akutansi Departemen/Lembaga, Unit Akutansi Eselon I, Unit Akutansi kantor Daerah Satuan Kerja, dan Unit Akutansi Proyek.

Kedua, dilihat dari-sudut rancangan 
sistemnya, akuntansi pemerintah baru ini merupakan adaptasi dari akutansi perusahaan terhadap lembaga pemerintah pusat. Itu tidak hanya tampak pada bentukbentuk laporan keuangan maupun klasifikasi rekeningnya, tapi juga pada konsepkesatuan usahanya. Yang dijadikan sebagai satuan usaha (entity) dalam sistem akutansi pemerintahan baru ini adalah lembaga pemerintahan pusat itu sendiri secara keseluruhan.

Berdasarkan kedua hal di atas, dapat dilihat bahwa akuntansi pemerintahan (pemerintah pusat) Indonesia di masa depan, bukanlah sistem akutansi dana sebagaimana dipraktikkan di AS. Kenyataan ini kembali mengundang timbulnya pertanyaan mengenai relevansi pengajaran akuntansi dana sebagai bagian dari materi ajaran akutansi pemerintahan.

Dengan telah disusunnya sistem akuntansi pemerintahan baru, tentu lebih relevan bila akutansi pemerintahan baru ini yang dimasukkan sebagai bagian dari silabus minimal pengajaran akuntansi pemerintahan. Yang agak mengganggu adalah bahwaperkembanganujicobasistem akuntansi pemerintahan baru itu, tampaknya tidak begitu lancar.

Dilihat dari sudut jangka waktu ujicobanya maka penguji cobaan akuntansi pemerintah baru itu hingga kini telah berlangsung selama 5 tahun. Sampai sejauh ini, selain pengujicobaan pada beberapa departemen sebagaimana telah dikemukakan tadi, belum ada perkembangan lebih lanjut yang dapat digunakan sebagai indikasi prospek penerapannya. Sebaliknya, justru ada indikasi bahwa ada pihak-pihak tertentu yang memang sengaja mencoba menghambat penerapannya (Sajihartana, 1992).

\section{Ototomi Daerah}

Bahwapemerintahan memiliki tekad untuk meningkatkan otonomi daerah, kiranya tidak perlu diragukan. Yang menjadi pertanyaan adalah sampai seberapa jauhkah sebenamya otonomi yang akan diberikan oleh pemerintah pusat kepada unit-unit pemerintah di daerah. Dalam kaitannya dengan pengajaran akuntansi pemerintahan, pertanyaanini sangat relevan untuk diajukan dan dicari jawabnya.

Dalam pengajaran akuntansi dana sebagaimana berlangsung selama ini, tampaknya adasemacam keyakinan bahwa tingkat otonomi unit-unit pemerintahan daerah Indonesia di masa depan akan sampai pada tingkat otonomi yang dicapai oleh unit-unit pemerintahan daerah sebagaimana di AS saat ini. Berdasarkan berbagai kenyataan yang telah dikemukakan sebelumnya, harapan semacam itu tampak masih merupakan hal yang terlalu berlebihan untuk kurun waktu saat ini. Dengan demikian, adalah kurang relevan bila issue otonomi daerah ini dijadikan sebagai argumen pengajaran akuntansi dana pada PTN/PTS di Indonesia.

Hal lain yang berkaitan dengan peningkatan otonomi daerah dan lebih relevan untuk dicermati dari sudut pengajaran akuntansi pemerintahan adalah mengenai penyempurnaan sistem akuntansi pemerintahan daerah. Di satu pihak, penyempumaan sistem akuntansi daerah ini adalah suatu kegiatan yang sama sekali terpisah dari penyempurnaan sistem akuntansi pemerintahan pemerintah pusat sebagaimana telah dikemukakan tadi.

Keterpisahan ini tidak hanya disebabkan oleh berbedanya lembaga konsultan yangmengerjakannya, melainkan juga disebabkan oleh berbedanya 
departemen pemerintahan yang bertanggung jawab terhadap kegiatan penyempumaan tersebut. Bila penyusunan sistem akuntansi pusat diselenggarakan di bawah koordinasi Departemen Keuangan, maka penyempumaan sistem akuntansi pemerintah daerah dikoordinasikan oleh Departemen Dalam Negeri.

Di pihak lain, bentuk penyempumaan yang diusulkan oleh Redecon hanyalah sekedarkomputerisasi dari sistem yang ada. Penyusunan sistem akuntansi pemerintahan daerah yang sama sekali banu akan dilakukan setelah komputerisasi dari sistem yang ada dianggap tidak memadai lagi.

Dengan demikian, bila dilihat dari sudut bentuk penyempurnaan yang dilakukan, penyempurnaan akuntansi pemerintah daerah memang tidak banyak artinya bagi kepentingan pengajaran akuntansipemerintahan. Yangkiranyalebih penting untuk dicatat bahwa proses penyempurnaan akuntansi pemerintahan daerah itu, temyata sama sekali dilakukan secara terpisah dari penyusunan sistem akutansi pemerintahan pemerintah pusat. Kenyataan ini jelasmenyebabkan timbulnya kesulitan untuk memprediksi bentuk akuntansi pemerintahan Indonesia di masa depan.

\section{Kesimpulan}

Berdasarkan beberapa pokok pikiran di atas, kiranya memang tidak keliru bila dikatakan bahwa pengajaran akuntansi pemerintahan di Indonesia berada di simpang jalan. Bahkan, bila dilihat dari sudut jumlah persimpangannya, situasi persimpangan yang dihadapi oleh pengajaran akuntansi pemerintahan di Indonseia bukanlah semata-mata situasi jalan bersimpang dua, melainkan situasi jalan bersimpang tiga, atau mungkin lebih. hemat saya, alternatif yang paling aman adalah dengan lebih menitik beratkan pengajaran akuntansi pemerintahan pada sistem yang berlangsung saat ini. Dengan penekanan seperti itu, tentu tidak berarti bahwa hal-hal seperti akuntansi dana dan akuntansi pemerintahan banu, sama sekali tidak diperkenalkan. Akan tetapi, bila dibandingkan dengan kecenderungan yang berlangsung saat ini, pengajaran akuntansi dana dalam hal ini tidak lagi sebagai materi pokok, tapi hanya sebagai materi pelengkap.

\section{Daftar bacaan}

Baswir, Revrisond, Akuntansi Pemerintahan Indonesia, Yogyakarta, BPFE, 1989.

Kosasih, Ruchyat, "Peran Akuntansi Pemerintahan di Indonesia", Makalah Untuk Seminar Nasional Peranan Akuntansi Dalam Dunia Bisnis dan Pemerintahan, Yogyakarta, $25-26$ Januari 1989.

"Pengukuran Pos-pos

Dalam Posisi Keuangan Pemerintah, Akuntansi, Edisi Khusus, Januari 1989. , "Rekomendasi Perubahan

Kebijaksanaan dan Prosedur Akuntansi Pemerintah", Akuntansi, No. 5, Mei 1989. ,"Perkiraan-perkiraan Buku Besar Akuntansi Pemerintah", Akuntansi, No. 9, September 1989.

Purba, Laudin, "Penyempurnaan Sistem Akuntansi Pemerintahan", Akuntansi, No. 9, September 1989.

Sajihartana, "Perlunya Akuntansi Pemerintah", Media Indonesia, 27 Juli 1992.

Sulistyo, Arie, F., "Kurikulum Bagi Akuntan Pemerintah", Akuntansi, No. 6, Juni 1987. 